\title{
T. Döring • M. Schwikowski · H.W. Gäggeler \\ Determination of lead concentrations and isotope ratios in recent snow samples from high alpine sites with a double focusing ICP-MS
}

\author{
Received: 2 December 1996 / Revised: 10 April 1997 / Accepted: 13 April 1997
}

\begin{abstract}
A double focusing ICP-MS, equipped with a Micro Concentric Nebulizer, has been used to determine concentrations and isotopic ratios of lead in recent snow samples (1993-1996) from high alpine sites in Switzerland. Concentrations varied between $0.02 \pm 0.002$ and $5.5 \pm$ $0.15 \mathrm{ng} / \mathrm{g}$ and are slightly lower than concentrations reported by Atteia [1], by Batifol et al. [2], and by Wagenbach et al. [3] for precipitation samples from similar remote sites in Europe. Since concentrations of lead in the fresh snow samples were mainly in the lower $\mathrm{pg} / \mathrm{g}$ range, the method to determine the isotopic ratios ${ }^{207} \mathrm{~Pb} /{ }^{206} \mathrm{~Pb}$ and ${ }^{208} \mathrm{~Pb} /{ }^{206} \mathrm{~Pb}$ had to be optimized. They could finally be determined with an average standard error of $0.14 \%$ within $12 \mathrm{~min}$ and a total sample consumption of $0.8 \mathrm{~mL}$. The average ratios ${ }^{207} \mathrm{~Pb} / 206 \mathrm{~Pb}$ and ${ }^{208} \mathrm{~Pb} /{ }^{206} \mathrm{~Pb}$ were 0.875 and 2.117, respectively. These values are comparable to isotopic compositions of lead in aerosols collected in Western Europe [4] and are less radiogenic than predicted by Grousset et al. [5]. Our data indicate that, although lead emissions from traffic have decreased largely during the last 10 years, the contribution from this source in modern snow is still detectable and seems to be equal to the lead input from other anthropogenic sources (e.g. waste incineration, industry).
\end{abstract}

\section{Introduction}

After the emission of anthropogenic and geogenic derived lead into the atmosphere, polluted air masses are transported from the source to high-alpine regions by strong convective mixing processes. Lead and other constituents are deposited on glaciers mainly during precipitation events. Therefore, similar to polar ice sheets, measure-

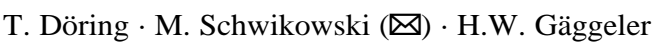
Paul Scherrer Institut, CH-5232 Villigen PSI, Switzerland

T. Döring $\cdot$ H.W. Gäggeler

Departement für Chemie und Biochemie, Universität Bern, Freiestrasse 3, CH-3012 Bern, Switzerland ments of lead deposition in snow and ice of high alpine glaciers can be used to determine trends of atmospheric air pollution. Compared to Greenland, where lead is assumed to originate mainly from North America and Eurasia [6], lead found in samples from the alpine area is assumed to be emitted from European sources. During the last 20 years leaded gasoline, the main source of atmospheric lead [7], has been produced with lead from precambrian ores $[8,9]$, characterized by a ${ }^{207} \mathrm{~Pb} /{ }^{206} \mathrm{~Pb}$ ratio of, for instance, 0.9617 from Broken Hill in Australia [5]. Thus, the isotopic composition of lead in the atmosphere contaminated by leaded gasoline is significantly different from the reported natural background ratio in central Europe $(0.833 \pm 1.3 \%)$ [8]. A systematic shift of the isotopic ratios to more radiogenic values with time, due to a reduction of anthropogenic lead in the atmosphere, was identified in European aerosols by Grousset et al. [5].

Compared to thermal ionization mass spectrometry (TIMS), the established method for determining isotopic compositions, inductively coupled plasma mass spectrometry (ICP-MS) offers the advantages of shorter analysis times and a less demanding sample preparation. On the other hand, the precision of TIMS is higher, since that of ICPMS is controlled by fluctuations, both in sample introduction and plasma and for our concentration range by the counting statistics (or concentrations).

In order to characterize the sources of lead in the present atmosphere, lead concentrations and the isotopic composition were determined by double focusing ICPMS in snow samples collected from two high-alpine sites in Switzerland during the last three years. It is the first time that lead isotope ratios in such a low concentration range have been measured by the ICP-MS technique.

\section{Experimental}

Sample preparation. Fresh snow from the surface and snow pit samples with a resolution of 5 to $10 \mathrm{~cm} /$ layer were collected on the Aletschgletscher (Jungfraujoch, $3450 \mathrm{~m}$ a.s.1.) and on the Grenzgletscher (Monte Rosa massif, $4200 \mathrm{~m}$ a.s.1.). The samples were stored in polypropylene bottles and were melted under acid condi- 
Table 1 Operating parameter settings of the ICP-MS device for the determination of lead isotopic ratios and concentrations

\begin{tabular}{lcl}
\hline & $\begin{array}{l}\text { Isotopic } \\
\text { ratios }\end{array}$ & $\begin{array}{l}\text { Lead } \\
\text { concentrations }\end{array}$ \\
\hline Magnet mass & 205 & 205 \\
Mass window & $50 \% *$ & $205.4-208.4$ \\
Segment duration [s] & 0.2 & 0.6 \\
Settling time [s] & 0.01 & 0.01 \\
$\begin{array}{l}\text { Sample time [s] } \\
\text { runs }\end{array}$ & 0.004 & 0.012 \\
passes & 2 & 1 \\
Analysis time [min] & 600 & 30 \\
for both methods & 12 & $3.5 * *$ \\
& $\begin{array}{l}\text { rf power: 1250 W; sampling and skim- } \\
\text { mer cone: Ni, 1.0 and 0.8 mm aperture } \\
\text { diameter, respectively; resolution: 300; } \\
\text { pulse counting mode; gas flow rates are } \\
\text { set to give max. intensities }\end{array}$ \\
\hline
\end{tabular}

* $50 \%$ of mass width

** time needed for the multielement method (including 25 isotopes)

tions $\left(0.1 \mathrm{~mol} / \mathrm{L} \mathrm{HNO}_{3}\right.$, Baker Ultrex II). After melting, a typical sample volume was about $5 \mathrm{~mL}$. Sample handling was always performed under class 100 clean room conditions.

ICP-MS measurements. For ICP-MS measurements a double focusing ICP-MS (ELEMENT, Finnigan MAT) equipped with a MCN-100 nebulizer (Cetac), operating in a self aspirating mode with an uptake of $40-60 \mu \mathrm{L} / \mathrm{min}$, and a double passed scott spray chamber cooled at $3^{\circ} \mathrm{C}$ was used. Sample introduction was performed by an autosampler (221XL, Gilson), under class 100 clean room conditions. The operating parameters used to determine the lead concentrations and the isotope ratios ${ }^{207} \mathrm{~Pb} / 206 \mathrm{~Pb}$ and ${ }^{208} \mathrm{~Pb} /{ }^{206} \mathrm{~Pb}$ are summarized in Table 1 . The detection limit $\left(3 \sigma_{\mathrm{b}}\right.$ criterion) was $3 \mathrm{pg} / \mathrm{g}$ and was controlled by the blank. The calibration curve used ranged from $10 \mathrm{pg} / \mathrm{g}$ to $2 \mathrm{ng} / \mathrm{g}$ with a sensitivity of $1.6-1.7 \times 10^{5} \mathrm{cps}$ for the ${ }^{208} \mathrm{~Pb}$ isotope $1 \mathrm{ng} / \mathrm{g}$ solution. A good agreement between concentrations measured by ICP-MS as well as graphite furnace atomic absorption spectroscopy was found $\left(\mathrm{r}^{2}=\right.$ 0.985 , slope $=0.97, n=20$ ).

To correct for mass bias and dead time effects, the measured lead ratios were calibrated against the NIST 981 lead isotopic standard. Solutions with different concentrations of the certified standard were measured after every 5 samples. For the $100 \mathrm{pg} / \mathrm{g}$ concentration level the standard error (SE) of the isotopic ratios for a 12 min measurement was about $0.14 \%$, i.e. 1.4 to 1.6 times higher than the theoretical standard error derived from counting statistics, but similar to precisions published recently by Vanhaecke et al. [10] obtained with much higher concentrations. The relative standard deviation (RSD) of repeated measurements of standards and samples during a day never exceeded twice the standard error (RSD $=0.1 \%$ for standards with $80 \mathrm{pg} / \mathrm{g}$ to $2 \mathrm{ng} / \mathrm{g}$ ). The isotopic ratios for a bulk standard and for the NIST 982 reference standard determined by ICP-MS measurements agreed well with TIMS measurements and with the certified values. The accuracy was smaller than two times the standard error for the concentration level of our samples $(0.28 \%$ ). For higher concentrations (5 to 10 $\mathrm{ng} / \mathrm{g}$ ) resulting in a standard error of $\pm 0.03 \%$ an accuracy of $0.08 \%$ could be obtained. Due to blank problems the samples with a lead concentration lower than $30 \mathrm{pg} / \mathrm{g}$ ( $2 \%$ of the samples) were rejected.

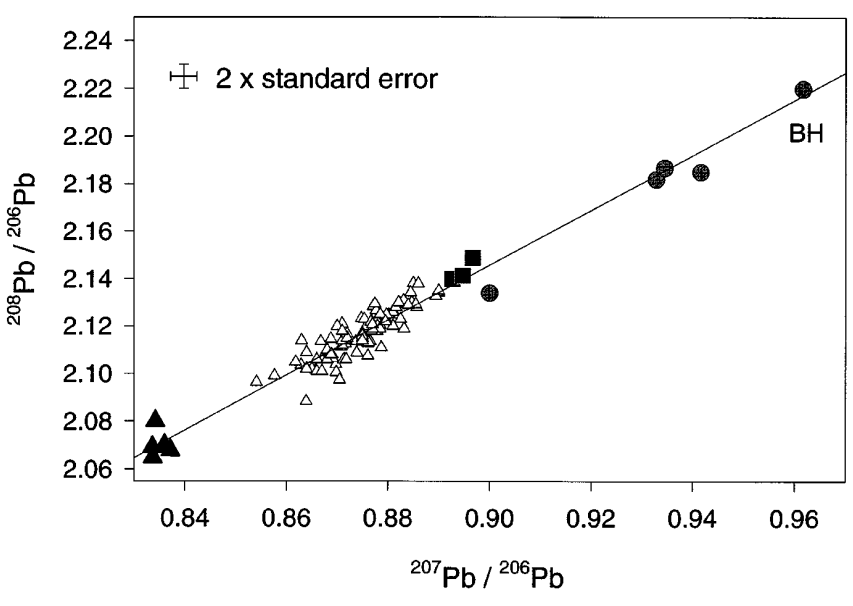

Fig. $1{ }^{208} \mathrm{~Pb} /{ }^{206} \mathrm{~Pb}$ ratios plotted versus ${ }^{207} \mathrm{~Pb} /{ }^{206} \mathrm{~Pb}$ ratios. $\triangle=$ recent snow samples from 1993-1996, supplemented by values $(\boldsymbol{A})$ from ratios of European geogenic material (own measurements and values from [5]), ratios of leaded gasoline in Europe (0) [4, 15] and values from leaded gasoline in Switzerland 1995/96 (ם) [16]. In addition, the lead isotopic ratio of Broken Hill ores in Australia (BH) is given (5). The line represents the linear correlation of all data $\left(r^{2}=0.93\right)$

\section{Results and discussion}

Concentrations of lead in recent snow, sampled between the years 1993 and 1996, ranged from $0.02 \pm 0.002$ to 5.5 $\pm 0.15 \mathrm{ng} / \mathrm{g}$ with a median value of $0.37 \mathrm{ng} / \mathrm{g}(n=220)$. They are an order of magnitude higher than values from Greenland ice $[6,7,11]$ and an order of magnitude lower than values reported for rain events over the northwestern Mediterranean [12] and the North Sea [13].

The mass spectrometric determination of lead isotopic ratios in snow samples was restricted mainly by small sample volumes and low lead concentrations, both resulting in a poor precision. To overcome this problem, the measurement time, the sample concentration and/or the instrument sensitivity must be increased. As discussed earlier by Feldmann et al. [14] the sensitivity of a doublefocusing ICP-MS is higher by a factor of ten to one hundred compared to quadrupole ICP-MS.

Indeed under equal conditions (same measurement times), our equipment allowed isotopic ratios for these kind of samples to be determined faster (factor 6), but with greater uncertainty (factor 4) than with the TIMS method.

The resulting isotopic ratios of 90 snow samples are plotted in Fig. 1, together with values from references [4, $5,15]$ and our own measurements of leaded gasoline, literature and measured values of geogenic material and a typical precambrian ore. The snow ratios ranged from 0.854 to 0.890 (avg: 0.875 ) for ${ }^{207} \mathrm{~Pb} /{ }^{206} \mathrm{~Pb}$ and from 2.088 to 2.138 (avg: 2.117) for ${ }^{208} \mathrm{~Pb} / 206 \mathrm{~Pb}$. All data plotted in Fig. 1 are highly correlated $\left(r^{2}=0.93\right.$, slope $\left.=1.16\right)$. The regression (solid) line can be interpreted as a line connecting the characteristic isotopic ratios of two different sources of lead. These are on the one hand, erosion of ma- 
terial like minerals, sediments etc. and, on the other hand, lead produced in anthropogenic processes from precambrian ore. Our values are in good agreement with data reported by Rosman et al. [11] for Greenland ice for the time period 1965 to 1988 , and by Hopper et al. [4] as well as by Altorfer [16], who determined lead isotope ratios in European atmospheric aerosol samples of 1988 (southern Sweden) and 1995 (Switzerland). Grousset et al. [5] published lead isotopic compositions in aerosol samples from the beginning of the 1980's to 1992 with a systematic shift towards more radiogenic ratios. The data from our work represent the years 1993 to 1996, but they are more similar to the values from Grousset et al. for the time period $1987-1989\left(0.879>{ }^{207} \mathrm{~Pb} /{ }^{206} \mathrm{~Pb}>0.865\right)$ [5]. For the short time period studied, no trend of the isotopic ratios could be observed. Hence, although the lead concentration in the atmosphere has decreased, the average isotopic composition has remained fairly constant during the last years.

The contribution of geogenic derived lead calculated using aluminium as a soil tracer was negligible, indicating that almost all lead found in the snow samples was introduced into the atmosphere by anthropogenic activities. The emissions from waste incinerators contain lead with a representative average of man made materials. The lead isotopic values in the exhaust of the waste incineration emissions from Bern $\left({ }^{207} \mathrm{~Pb} /{ }^{206} \mathrm{~Pb}\right.$ : $0.870 ;{ }^{208} \mathrm{~Pb} /{ }^{206} \mathrm{~Pb}$ : 2.110) [16] were equal to values reported by Hamester [17] for waste incinerators in Germany. They fit very well to the more radiogenic ratios from our data which are mainly distributed between actual values from leaded gasoline $\left({ }^{207} \mathrm{~Pb} /{ }^{206} \mathrm{~Pb}\right.$ : $\left.0.895 ;{ }^{208} \mathrm{~Pb} /{ }^{206} \mathrm{~Pb}: 2.143\right)$ and the value obtained from waste incineration exhaust. Thus, we conclude that, even in today's snow samples, the contribution of leaded gasoline is still equal to that from other anthropogenic sources (waste incineration, industry).
Acknowledgments We thank Dr. A. Döscher, M. Lugauer, S. Brütsch, and V. Lavanchy for their help in the field, L. Tobler, Dr. S. Nyeki, Prof. Dr. B. Eichler, and Dr. R. Frei for helpful discussions.

\section{References}

1. Atteia O (1994) Atmos Environ 22:3617-3624

2. Batifol FM, Boutron CF (1984) Atmos Environ 18:2507-2515

3. Wagenbach D, Münnich KO, Schotterer U, Oeschger H (1988) Annals of Glaciology 10:183-187

4. Hopper JF, Ross HB, Sturges WT, Barrie LA (1991) Tellus 43B:45-60

5. Grousset FE, Quétel CR, Thomas B, Buat-Ménard P, Donard OFX, Bucher A (1994) Environ Sci Technol 28:1605-1608

6. Boyle EA, Sherrell RM, Bacon MP (1994) Geochim Cosmochim Acta 58:3227-3238

7. Rosman KJR, Chisholm W, Boutron CF, Candelone JP, Hong S (1994) Geochim Cosmochim Acta 58:3265-3269

8. Moor HC, Schaller T, Sturm M (1996) Environ Sci Technol 30:2928-2933

9. Krause P, Kriews M, Dannecker W, Garbe-Schönberg C-D, Kersten M (1993) Fresenius J Anal Chem 347: 324-329

10. Vanhaecke F, Moens L, Dams R, Taylor P (1996) Anal Chem 68: $567-569$

11. Rosman KJR, Chisholm W, Boutron CF, Candelone JP, Görlach U (1994) Nature 362:333-335

12. Migon C, Alleman L, Leblond N, Nicolas E (1993) Atmos Environ 27A:2161-2167

13. Dannecker W, Hinzpeter H, Kirzel H-J, Luthardt H, Kriews M, Naumann K, Schulz M, Schwikowski M, Steiger M, Terzenbach U (1994) In: Sündermann J (ed) Circulation and Contamination Fluxes in the North Sea. Springer Verlag, Berlin Heidelberg New York, pp138-189

14. Feldmann I, Tittes W, Jakubowski N, Stuewer D, Giessmann U (1994) J Anal At Spectrom 9:1007-1014

15. Horn P, Hölzl S, Schaaf P (1993) Isotopenpraxis 28:263-272

16. Altorfer T (1996) Diploma Thesis, Universität Bern

17. Hamester M, Stechmann H, Krause P, Dannecker W (1992) Analytical Proceedings 29:293-296 